\title{
EU NEW MEMBER STATES HOUSEHOLDS' BANKING INDEBTEDNESS AND IT'S IMPLICATIONS: AN OVERVIEW
}

\author{
Angela Roman ${ }^{1}$ \\ Alina Camelia Şargu ${ }^{2}$
}

\begin{abstract}
During the period previous to the crisis, most of the EU new member states from our research (especially Bulgaria, Czech Republic, Estonia, Hungary, Latvia, Lithuania, Poland and Romania) have registered a fast growth of the households indebtedness, which has lead to the extension of the vulnerabilities of this sector in front of some macroeconomic shocks. In this context, our research aim to especially comparatively underline the stylised facts about the indebtedness degree of the households from the analysed countries and the main effects generated by the fast growth of the banking debts of this sector. Through the undertaken analysis in our research we aim at underling the major importance which the insurance of a sustainable household's indebtedness level has for the macroeconomic and financial stability of a country.
\end{abstract}

Key words: households' indebtedness, new EU member countries, vulnerabilities, loans to households, global crisis

JEL Codes: G21, E44, E51, R20

\section{Introduction}

In the last years prior to the start of the global financial and economic crisis in September 2008, most of the new EU member states have registered a high growth of the banking credits granted to households which has lead to a significantly increase of the indebtedness level of this sector. Such an evolution took place in the context of an international economic environment characterised by an abundance of liquidity and low interest rates, but also as a result of an internal favourable economic environment, which has registered a high economic growth rate, a diminishing of the inflation and of the interest rates, a raise of the households income and of the price of assets, especially in the real estate sector.

The rapid expansion of the banking indebtedness of households has generated a series of positive effects on the welfare of households, credit institutions and the overall economic environment (BIS, 2009: 2). The easy access of households to credits has determined on the one hand to an increase of their consumption, the ease of acquiring a house, the consolidation of the housing market, the raise of the credit institutions profitability and lead also to the improvement of the macroeconomic environment, especially through the enhancement of the business environment and the raise of the level of labour employment. On the other hand, the rapid and unsustainable growth of the indebtedness level of households has lead to an increase of the vulnerabilities of this sector as a result of macroeconomic shocks, which can have negative implications on the macroeconomic and financial stability.

The recent global financial and economic crisis had an extremely negative impact on households. The depreciation of the macroeconomic environment, the strengthening of the credit standards, the diminishing of the assets value, especially in the case of real estates, have lead to a

\footnotetext{
1 Alexandru Ioan Cuza University, Faculty of Economics and Business Administration, Iasi, Romania, email: aboariu@uaic.ro

2 Alexandru Ioan Cuza University, Faculty of Economics and Business Administration, Iasi, Romania, email: s_alina_camelia@yahoo.com
} 
strong depreciation of the financial status of households, with an extremely negative impact on the quality of the bank's credit portfolios, but also on the demand and supply of goods and services.

Our research is structured as follows: the first part contains the introductory remarks regarding the importance and the relevance of the approached research theme; the second part is dedicated to a literature review; the third part underlines the main characteristics of the financial situation of households from the analysed countries; the forth part of the research reflects stylized facts about the banking indebtedness level of households from the panel countries; while part five reflects the main effects determined by the rapid growth of the banking indebtedness level of this sector in the context of the financial crisis; part six contains the concluding remarks.

\section{Literature review}

The rapid growth of the banking credits for households in most of the new EU member states in the years previous to the global financial crisis has lead to an accelerated growth of the indebtedness of this sector, which have in term attracted the attention of a significant number of researchers which were interested in finding the answerer to the question that the rapid growth of the banking credits to households underline a progress in the financial convergence process or represents an unsustainable growth, which will lead to a series of macroeconomic and financial imbalances. Thus, Hilbers et al (2005) and Sirtaine et Skamnelos (2007) have underlined the fact that the merging European countries have registered a very rapid growth of the credits for the private sector which reflects in part progresses achieved in the convergence process, signaling also the fact that there are significant macroeconomic and financial imbalances which will need to be addressed by an appropriate set of measures. Comparatively, Backé, Égert Balázs et Walko (2007) have concluded that in some of the new EU member countries the level of credits granted to the private sector in GDP is close to equilibrium, while in some other countries this level is high according to the economic fundaments.

Other fundamental aspects addressed in the academic literature regarding the indebtedness level of households aim the determining factors and the effects the indebtedness of this sector. Thus, the research undertaken by Karen et Kohn (2007) using the example of the USA in the period after 1980, concludes that the raise of the real estate prices and financial innovation represent the main factor which have lead to the raise of the indebtedness level of the households sector. The research undertaken by Debelle (2004), underlines the fact that in the last two decades, the raise of the households indebtedness was greatly attributed to the effects of two major factors, namely the diminishing of the interest rates and the easing of liquidity constraints after the financial deregulation process from the early 1980. Meanwhile, the research studies the macroeconomic implications of the household's indebtedness and concludes that the enhancement of the debt level raises the sensitivity of the sector to the variations of the interest rates, income and assets prices.

Regarding the effects of the households indebtedness, the research undertaken by Büyükkarabacak et Valev (2010) underline the fact the rapid expansion of credits for households was, compared to the credit expansion for enterprises, a more statistically and economically significant predictor of banking crises and that a differential policy for targeting household credit may reduce the likelihood of crisis without limiting the favourable effects of the credit growth for enterprises.

The research of Cecchetti, Mohanty et Zampolli (2011) studies the relationship between the level of government, non-financial corporations and households debt, on a sample of 18 OECD countries between 1980 and 2010. Through this, the authors underline the fact that a moderate level of the indebtedness improves welfare and enhances the economic growth, while a high level of debt, over a certain point, can have significant negative implications.

The academic studies from Romania which are focused on the aspects regarding the household's indebtedness are relatively low, one of the best studies being the one undertaken by Neagu and Mărgărit (2005). Their research has underlined especially the determining factors of the 
Romanian household's indebtedness and the risks which can be generated by this sector in the financial stability framework. Also, the authors conclude that despite the fact that the Romanian household's indebtedness has not generated systemic risks on the national financial system, between 2000 and 2004, but these problems can appear in the near future.

\section{Research methodology}

In order to evaluate and analyse the level of indebtedness of the households from the new EU member countries from our panel (Bulgaria, Czech Republic, Estonia, Hungary, Latvia, Lithuania, Poland and Romania), we first underlined the main characteristics of the financial positions of the households, which will allow us to make appreciations regarding the capacity of this sector to resists to macroeconomic shocks. Also, in order to comparatively analyse the indebtedness level of the households from the panel countries and the effects of it rapid growth we will use a series of significant indexes and indicators. This approach will allow us to underline the major importance of a sustainable level of indebtedness for the households in order to preserve the macroeconomic and financial stability.

In our research, the term households refers, according to the Eurostat methodology, to households and non-profit institutions serving households, while the term banking debts of the households refers to the banking credits granted to this sector, as aggregate data on the debt service and in general to the balance sheets of households are unavailable.

Our research is based on a macroeconomic analysis of the household's indebtedness, using data provided by ECB, Eurostat, AMECO, IMF and also different reports and researches.

The difficulties regarding the availability of statistical data regarding the indebtedness level of households, especially on the different categories, determines a series of limitations to all researches undertaken on this theme, which would be surpass as central banks will take a more active approach regarding the analytical analysis of the households balance sheets, starting from a common methodology which will ensure a comparability of the data and the obtained results among countries.

\section{Evolutions and characteristics of the financial position of households in the panel countries}

The approach of this theme is motivating because the financial position of households significantly affects the capacity of this sector to honour their debts, which in term influences the balance sheets of the banking sector and the demand and the supply of goods and services in the economy.

In order to analyse the financial situation of the households we consider of great interest to analyse the evolution of the net financial wealth (see table no. 1) and that of the financial assets and liabilities of this sector, as a result of the impact that these characteristics are having on the households capability to withstand economic shocks, especially the ones related to income and the debt service.

The net financial wealth of the households as percentage of GDP has registered in 2008 compared with 2005 a diminishing in most of the panel countries, especially as a result of a new wave of credit contracted by households and to a lesser extent because of the diminishing of the financial assets prices as a result of the financial and economic crisis in September 2008. Also, we must underline the fact that the diminishing of the net financial worth has happened as the households preferences for real estate assets grew. On the other side, we must also underline the lower ratio of the net financial wealth in GDP registered by the panel countries compared with the euro zone and EU-27 average despite some progresses in the convergence process, this evolution underling the lower level of wealth that these households have. Moreover, the diminishing of the net financial wealth can be attributed also to the fact that financial assets have register between 
2005 and 2008 a lower growth rate that the financial liabilities in most of the panel countries (see table no. 1). Such an evolution underlines the raise of the household's vulnerabilities against possible shocks in an unfavourable macroeconomic environment.

Table no. 1

The evolution of the financial indicators for households, in 2005, 2008 and 2009

\begin{tabular}{|c|c|c|c|c|c|c|c|c|}
\hline \multirow[t]{2}{*}{ Country } & \multicolumn{2}{|c|}{$\begin{array}{c}\text { Financial Assets } \\
\text { (\% of GDP) }\end{array}$} & \multicolumn{2}{|c|}{$\begin{array}{c}\text { Financial } \\
\text { Liabilities } \\
\text { (\% of GDP) }\end{array}$} & \multicolumn{2}{|c|}{$\begin{array}{c}\text { Net Financial } \\
\text { Wealth* } \\
\text { (\% of GDP) }\end{array}$} & \multirow[t]{2}{*}{$\begin{array}{l}\text { Average yearly } \\
\text { growth rate of } \\
\text { financial assets }\end{array}$} & \multirow{2}{*}{$\begin{array}{l}\text { Average yearly } \\
\text { growth rate of } \\
\text { liabilities } \\
\text { financial }\end{array}$} \\
\hline & 2005 & 2008 & 2005 & 2008 & 2005 & 2008 & & \\
\hline BG & 68,03 & 87,38 & 17,98 & 35,07 & 50,05 & 52,31 & 26,51 & 47,85 \\
\hline $\mathrm{CZ}$ & 81,23 & 77,63 & 35,18 & 29,99 & 46,05 & 47,63 & 12,37 & 15,21 \\
\hline $\mathbf{E E}$ & 101,47 & 116,94 & 45,02 & 60,61 & 56,45 & 56,33 & 24,50 & 33,12 \\
\hline HU & 87,27 & 90,01 & 26,10 & 37,26 & 61,17 & 52,75 & 8,90 & 19,66 \\
\hline $\mathbf{L V}$ & 67,76 & 49,54 & 32,31 & 48,58 & 35,45 & 0,96 & 16,12 & 53,25 \\
\hline LT & 58,57 & 69,75 & 17,13 & 35,46 & 41,45 & 34,29 & 22,50 & 50,61 \\
\hline PL & 81,35 & 61,94 & 16,49 & 26,29 & 64,86 & 35,65 & 10,20 & 31,79 \\
\hline RO & 54,90 & 62,91 & 13,28 & 26,77 & 41,63 & 36,14 & 35,44 & 62,17 \\
\hline EU27 & 208,33 & 180,87 & 69,80 & 70,31 & 138,53 & 110,57 & 2,51 & 5,74 \\
\hline Euro area & 200,47 & 185,77 & 65,04 & 68,40 & 135,43 & 117,38 & 3,55 & 6,87 \\
\hline
\end{tabular}

The liabilities structure reflects the significant dependency of the households sector to the financing provided by the credit institutions. Thus, in all of the panel countries, in 2008, the loans have a ratio of $70 \%$ in the total liabilities portfolio of the households (see fig. no. 1). It is worth mentioning also the fact that in some countries (Bulgaria, Estonia and Romania) a major part of the liabilities portfolio is represented by other financial instruments, like shares and other equity, as a result that in the households sector were included also the unincorporated enterprises and some of the non-profit institutions (Eurostat, 2009: 6).

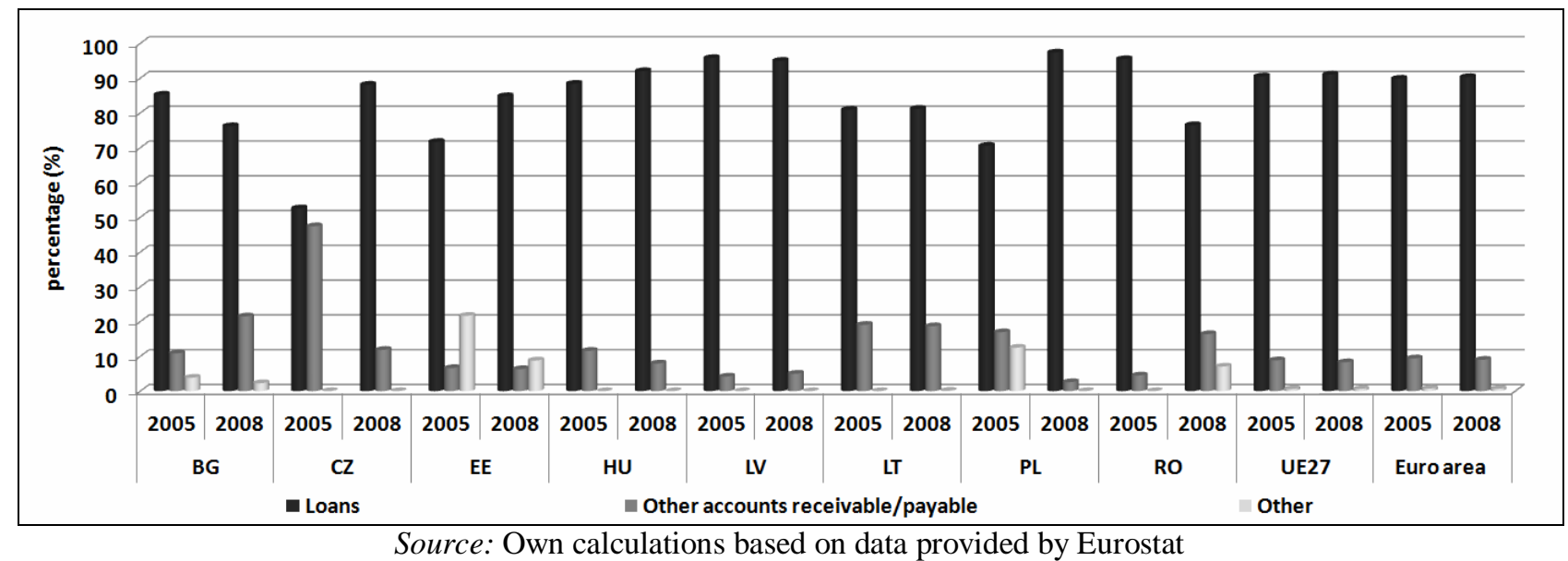

Fig. no. 1 - The portfolio structure of the financial liabilities of households

In regard to the structure of the financial assets held by the households, these underline their preference for certain financial instruments. From this perspective there are a series of differences among the panel countries: in Estonia, Romania, Lithuania and Bulgaria the households preferred to own in 2008 to a higher degree shares and other equity while in the case of the Czech Republic, Hungary, Latvia and Poland most of the households preferred currency and deposits, a similar situation to the one registered in the euro zone and at the EU-27 level (see fig. no. 2). In the case of 
the first group of countries, the financial assets portfolio can be problematic, especially in the context of drop in the value of the financial assets market.

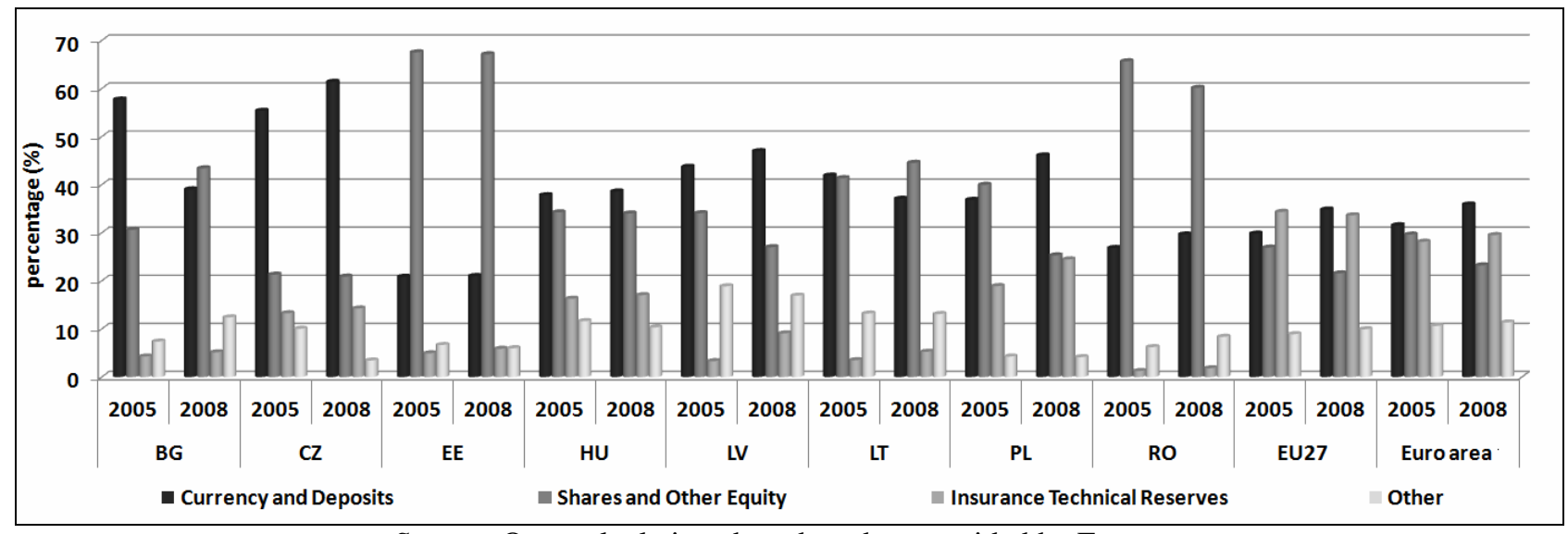

Source: Own calculations based on data provided by Eurostat

Fig. no. 2 - The portfolio structure of the financial assets of households

Overall, the evolution of the net financial wealth, of the financial assets and liabilities of the households from the panel countries has underlined the diminishing of the capacity of this sector to handle economic shocks and has generated concerns regarding the implications of this evolution on the financial stability of the interest rates risk and that of the risk associated with the fluctuation of the financial assets value. Also, the underlined evolution has signaled a increase of the risks both on the financial assets and liabilities side. The risks generated on the financial assets side are determined especially by the increase of the investments ratio on lease liquid and higher returns assets. In regard to the liability side, the risks are determined especially by the increase of the banking indebtedness level of households.

\section{The evolution of the indebtedness level of households in the case of the panel countries}

In the last years prior to the start of the recent global financial crisis one of the most significant characteristics which has market the banking loaning process in the panel countries was the rapid expansion, express to a two digit growth rate, of the banking loans granted to households, which have been considered the main engine behind the banking loans expansion granted to the economy. Between 2005 and 2008 the fasted growth rate has been registered by Romania, the Baltic States and Bulgaria, where the average yearly growth rate of loans to households was approximately $72 \%$, over $46 \%$ and respectively $43,24 \%$ (see fig. no. 3 ).

The extremely rapid growth of the banking loans for households has determined also a growth of the indebtedness level of these in most of the panel countries. Thus, the banking indebtedness of households, compounded as percentage of the bank loans to GDP has grown significantly from 7,28\% in 2005 (in the case of Romania) to 47\% in 2008 (in the case of Estonia) (see fig. no. 4). In 2009 due to the diminishing of the growth rate of banking loans granted to households, the indebtedness rate of households grew as a result of the diminishing of the GDP as a result of the economic recession. 


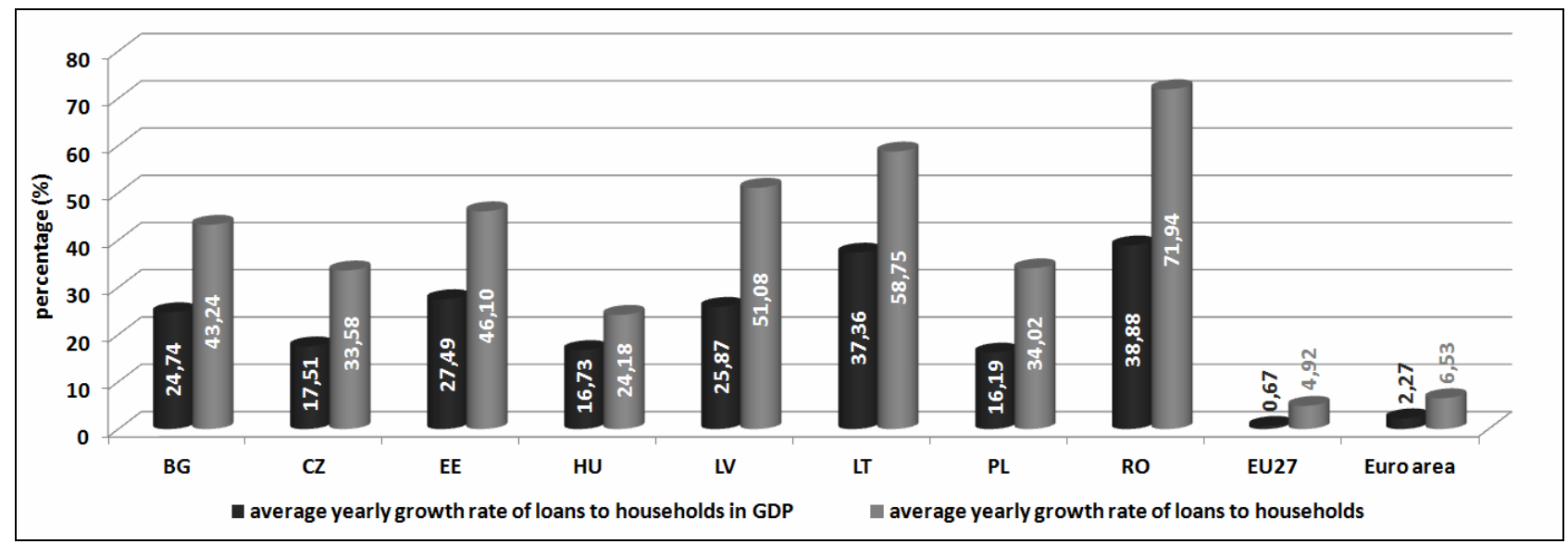

Source: Own calculations based on data provided by ECB, 2008, 2010 and Eurostat

Fig. no. 3 - Evolution of average yearly growth rate of household's indebtedness between 2005 - 2008

In comparison with the euro zone and the EU-27 average, in most of the panel countries, the banking indebtedness level of households is lower, but the most problematic is the growth rate which between 2005 and 2008 registered a double digits evolution in all of the analysed countries. The most significant growth of the banking indebtedness level of households has been registered by Romania, Lithuania and Estonia, where the average yearly growth rate of loans to households in GDP was between 2005 and 2008 of 39\%, over 37\% and respectively 27\% (see fig. no. 3).

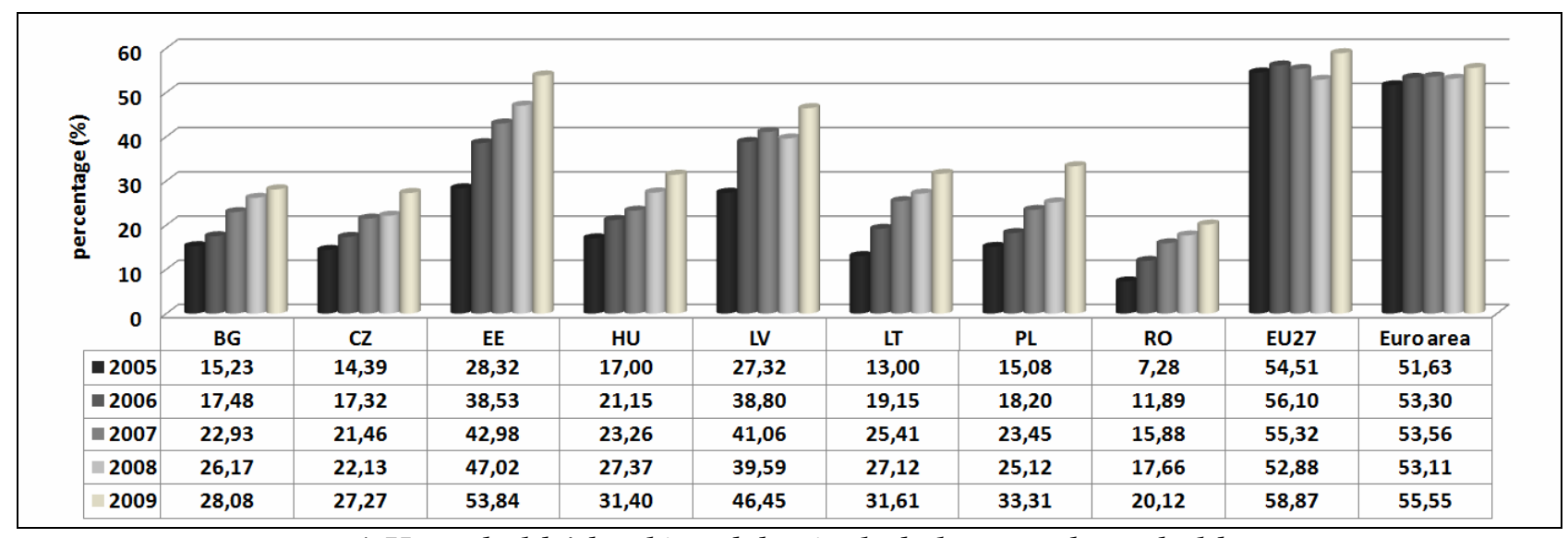

* Households' banking debts include loans to household

Source: Own calculations based on data provided by ECB, 2008, 2010 and Eurostat

Fig. no. 4 - The evolution of the households banking debts* to GDP ratio

In order to assess the indebtedness level of households we consider two main indicators, namely the ratio of household loan to gross disposable income and the ratio between the loans granted to households and their financial assets, these indicators providing information's regarding the ability of households to honor their banking debts. Regarding the first indicator it is worth mentioning it extremely rapid growth from 11,73\% in 2005 (in Romania) to 85,73\% in 2008 (in Estonia) (see table no. 2). Also, it is worth mentioning the extremely rapid development with over $110 \%$ of the growth rate of the credits granted to households as percentage of the total gross disposable income in Romania and Lithuania, as a result of the much faster growth of the credits contracted by households compared with the growth of their gross disposable income. Such an evolution have generated concerns as a result of the negative impact that it has on the ability of 
households to honor their debt obligations to banks in the context of negative shocks on income, the interest rate, the currency exchange and the price of assets.

Table no. 2

Ratio of Household loan to gross disposable income* (percentage)

\begin{tabular}{lrrrrrrrrrr}
\hline & BG & CZ & EE & HU & LV & LT & PL & \multicolumn{1}{c}{ RO } & EU27 & Euro area \\
\cline { 2 - 10 } $\mathbf{2 0 0 5}$ & 28,67 & 27,27 & 54,45 & 27,84 & 43,07 & 20,05 & 22,25 & 11,73 & 83,51 & 77,74 \\
$\mathbf{2 0 0 8}$ & N/A & 40,50 & 85,73 & 48,03 & 60,71 & 42,82 & 39,21 & 27,53 & 82,13 & 80,73 \\
$\mathbf{2 0 0 9}$ & N/A & 49,37 & 90,93 & 54,28 & 70,42 & 42,60 & 51,31 & N/A & 87,9 & 81,66 \\
Growth 2008/2005 & N/A & 48,51 & 57,45 & 72,52 & 40,96 & 113,57 & 76,22 & 134,70 & $-1,65$ & 3,85 \\
\hline
\end{tabular}

* gross disposable income of households and non-profit institutions serving households

Source: Own calculations based on data provided by ECB, 2010 and AMECO

In regard to the second mentioned indicator it is noteworthy it deterioration at an alarming rate in all the analysed panel countries with over 30\% in 2008 compared with 2005 (see fig. no. 5) especially in Poland (with over 118\%), Romania (with over 111\%), Latvia (with over 98\%) and Lithuania (with over 75\%). Such an evolution is determined by the net superior growth rate of loans to household's compared with the growth rate of financial assets. Still, the fast growth of this indicator underlines also an increase of the household's vulnerabilities to macroeconomic shocks.

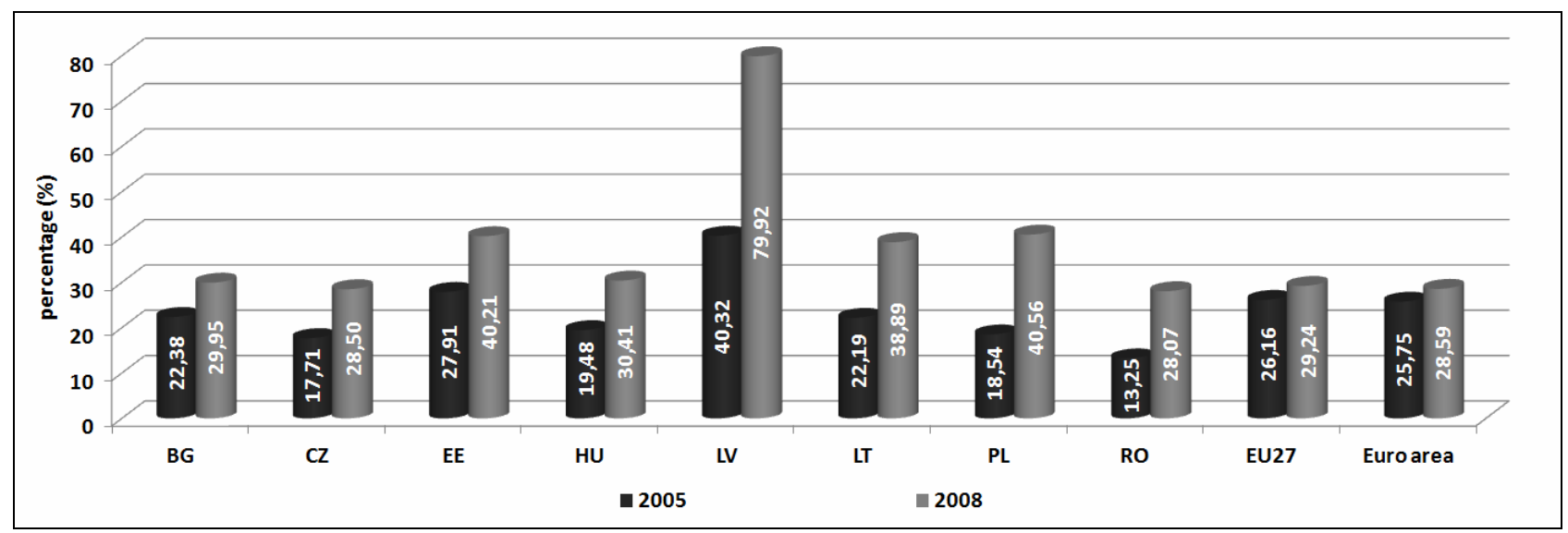

Source: Own calculations based on data provided by ECB, 2010 and Eurostat

Fig. no. 5 - The evolution of the ratio between loans to households and financial assets

The significant raise of the indebtedness of households has determined the enhancement of the demand for the demand and supply for credits, but also by the governmental policies which supported the loaning process of households through tax incentives and government-sponsored institutions. Additional to these factors, the prices of assets, especially the housing prices have stimulated the household lending process. In regard to the demand, the rapid economic growth, the increased revenues of households, the diminishing of the inflation and interest rates and the urbanization have stimulated the raise of the indebtedness level of households. On the supply side, financial deregulations, financial innovations, technological progresses and the diminishing of the demand for enterprises credits have contributed to the enhancement of the availability of loans for households (BIS, 2009). As a effects of the influence of these factors the loans granted to households have registered an increase in the total amount of banking loans granted to the economy, in 2008 compared with 2005, in most of the panel countries (see fig. no. 6) which signifies an increase of the bank's exposure to the households sector similar to the one of the euro zone or the EU-27 average. The most significant increases have been registered by Romania, Lithuania and Hungary, where the ratio of the loans granted to households has increased in 2008 compared with 2005 by $34,5,23,76 \%$ and respectively $23,36 \%$. 


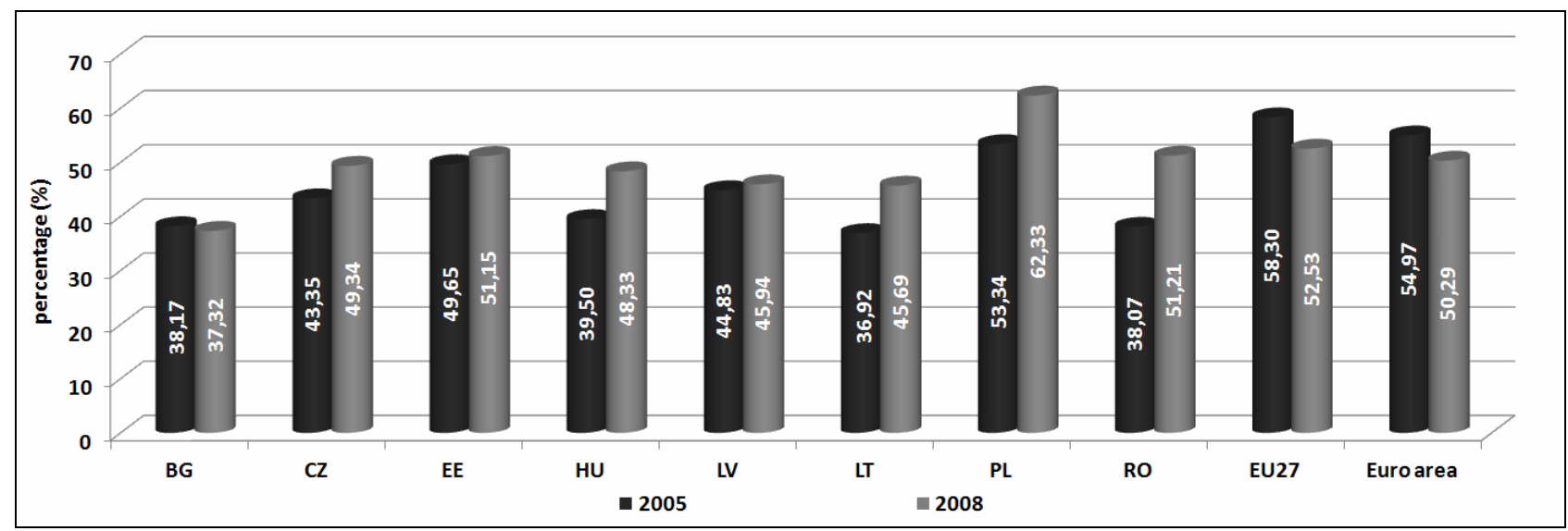

Source: Own calculations based on data provided by ECB

Fig. no. 6 - Share of loans to households in loans to economy

In terms of the structure of the households banking indebtedness by purpose it is noteworthy the fact that in 2008, with the exceptions of Bulgaria and Romania, the loans for housing perchance are representing the most important component in all of the panel countries, a situation similar to the one in the euro zone and the EU-27 average (see fig. no. 7). It is also noteworthy the accelerated dynamic of the loans for housing purchase comparatively with consumer credit, in most of the panel countries, but especially in the one that have started from a lower housing loans level like Romania and Bulgaria. These two countries have registered the fastest growth of the ratio of loans for housing purchase in GDP, in 2008 compared with 2005, of approximately $288 \%$ and respectively $160 \%$. In this context the loans for housing purchase have represented the main engine for the growth of the households banking indebtedness level.

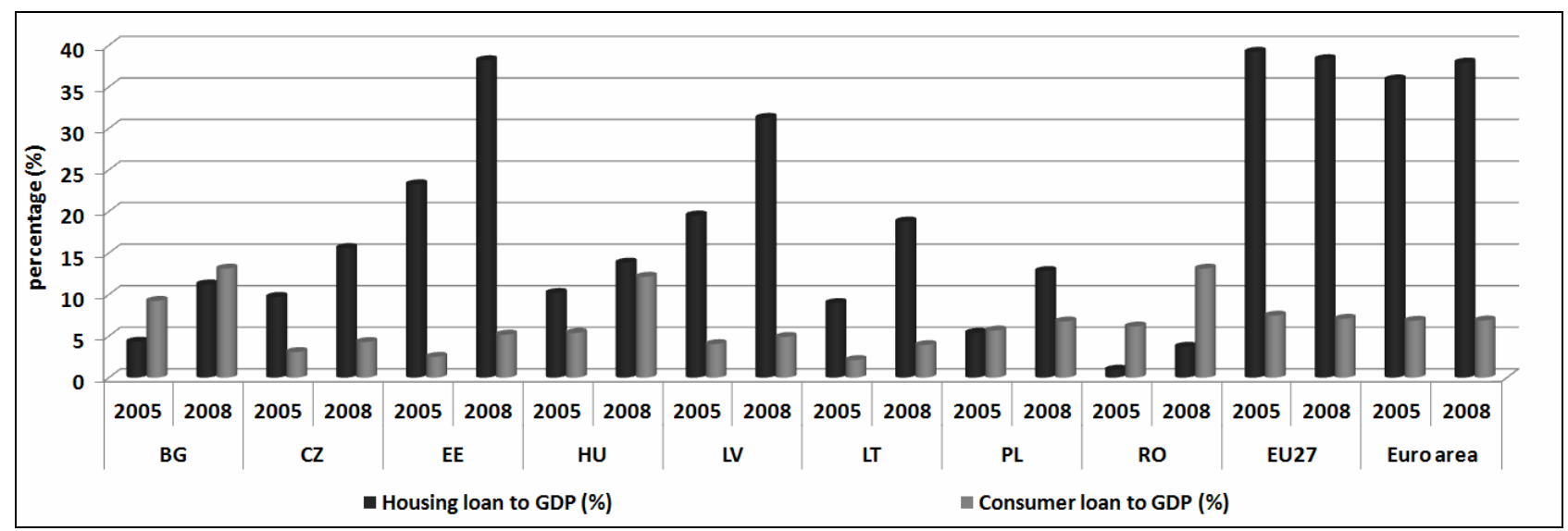

Source: Own calculations based on data provided by ECB and Eurostat

Fig.no. 7 - The evolution of households banking indebtedness by purpose as \% of GDP

The rapid growth of the loans for housing purchase has been determined by the growth of the demand and supply for housing. From the demand side, the enhancement was stimulated by the growth of the income, the improvement of the expectations regarding future revenues, the diminishing of the interest rates, and in some countries because of the housing subsidy systems, the favorable tax treatment of housing loans, like in the case of the Czech Republic, Estonia, Lithuania and Hungary (ECB, 2009: 21). From the supply side perspective, the enhancement of the completion among banks and the financial innovations have lead to a diversification of the credit instruments, which have become available at a lower price and shorter maturities.

A significant characteristic of the households banking indebtedness in most of the panel countries is determined by the high ratio of the banking debts expressed in a foreign currency in the 
total amount of the housing loans portfolio (see fig. no. 8), which was determined both by the demand and the supply. The demand was stimulated by the interest rate differential between the interest rates at the foreign currency denominated loans and the interest rates for the loans denominated in the domestic currency and by the increase of the wages. The supply was also stimulated in the context of limited savings, the banks preferred to grant loans as a direct consequence of the easy access they had to external financing sources.

In all the analyzed panel countries, except for Bulgaria, the share of these loans is above $60 \%$. In this respect, extremely high shares, namely over $90 \%$ were registered in Latvia, Romania and Estonia, thus increasing significantly the exposure of the households to the national currency depreciation risk. By contrast, in Czech Republic the foreign currency lending of households is almost inexistent (below 1\%) and is therefore not reflected in figure no. 8 .

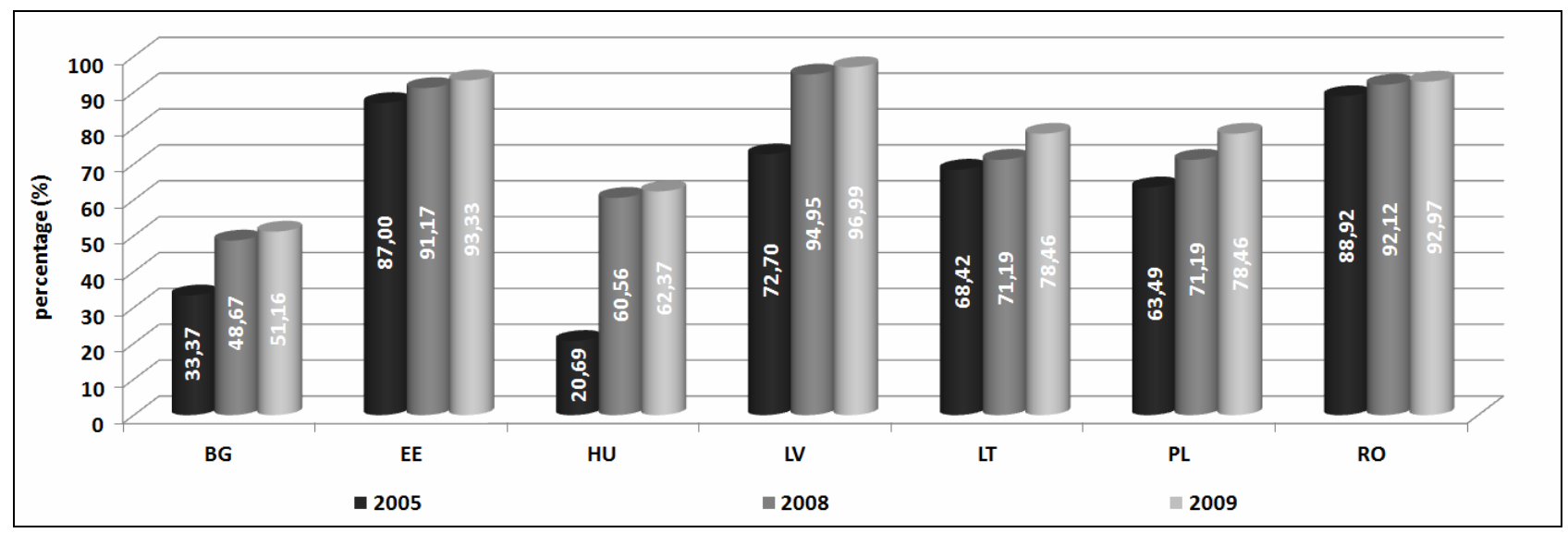

Source: (ECRI, 2010)

Fig. no. 8 - Share of foreign currency-denominated loans in housing loan portfolio, in 2005, 2008 and 2009

The enhancement of the banking indebtedness for housing purchasing, especially in foreign currency has triggered a significant raise of the housing prices, the credit risks and of the exposure of banks to the evolutions of the real estate market. Based on the available data is notable the strong growth of the housing prices especially in Lithuania, Bulgaria and Estonia (see fig. no. 9).

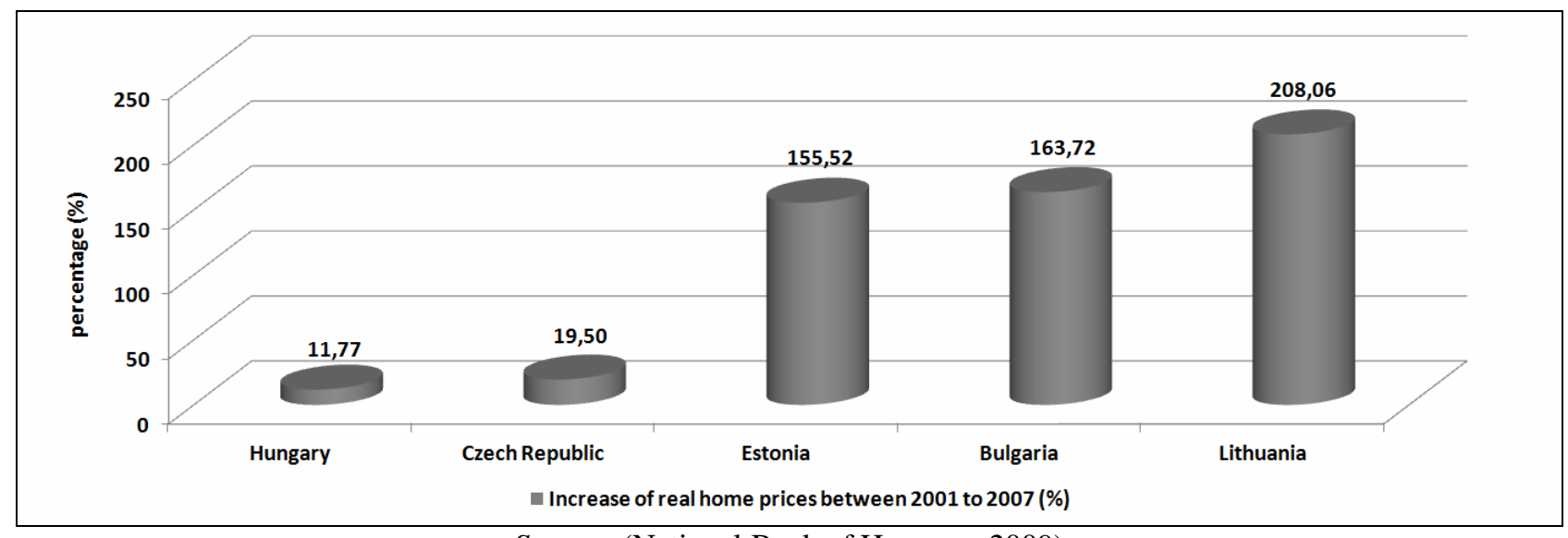

Source: (National Bank of Hungary, 2009)

Fig. no. 9 - Increase of real home prices from 2001 to 2007 (\%) 


\section{The effects determined by the rapid expansion of the household's indebtedness}

The rapid growth of the banking indebtedness of households has lead in the years previous to the start of the recent financial and economic crisis to major macroeconomic and financial imbalances, which were amplified as a result of the economic recession. At the macroeconomic level, in most of the new EU member countries there has been a significant raise of the internal demand for goods and services and implicitly a raise in consumption, which has become the main engine of the production raise. Still, in the context of a insufficient offer of goods and services the increase of the internal demand, financed heavily through loans, has triggered pressures on inflation and the dangerous raise of the account deficits, mainly in the case of Bulgaria, the Baltic States and Romania, especially between 2007 and 2008 (see table no. 3). Also, the deepening of the current account deficit registered came as a result of the high growth of the mortgages debts and the price of housing, which have lead to a boom in the construction sector, which triggered an increase of the demand for imports. Therefore, the countries that have registered the highest rates of growth of the households banking indebtedness have also been exposed to some external financial vulnerability. Financially, the significant raise of the mortgagees debts, especially the ones denominated in foreign currencies which were contracted at a variable interest rate, have lead to a significant increase of the housing prices, the raise of the exposure of households to currency and interest rate risks, the enhancement of the bank's credit risks and their exposure to the evolution of the real estate market.

Table no. 3

The evolution of the main macroeconomics indicators for the panel countries between 2006 and 2010

\begin{tabular}{|c|c|c|c|c|c|c|c|c|c|c|}
\hline & \multicolumn{5}{|c|}{ GDP growth rate } & \multicolumn{5}{|c|}{ Domestic demand, volume* } \\
\hline & 2006 & 2007 & 2008 & 2009 & 2010 & 2006 & 2007 & 2008 & 2009 & 2010 \\
\hline BG & 6,5 & 6,4 & 6,2 & $-5,5$ & 0,2 & 10,8 & 8,8 & 6,5 & $-12,8$ & $-4,6$ \\
\hline $\mathbf{C Z}$ & 6,8 & 6,1 & 2,5 & $-4,1$ & 2,3 & 5,4 & 5,2 & 1,2 & $-3,7$ & 1,4 \\
\hline $\mathbf{E E}$ & 10,6 & 6,9 & $-5,1$ & $-13,9$ & 3,1 & 16,5 & 9,6 & $-11,0$ & $-23,4$ & 1,4 \\
\hline HU & 3,6 & 0,8 & 0,8 & $-6,7$ & 1,2 & 1,4 & $-1,3$ & 0,8 & $-10,8$ & $-1,1$ \\
\hline $\mathbf{L V}$ & 12,2 & 10,0 & $-4,2$ & $-18,0$ & $-0,3$ & 18,1 & 12,4 & $-10,1$ & $-27,6$ & $-0,9$ \\
\hline LT & 7,8 & 9,8 & 2,9 & $-14,7$ & 1,3 & 9,1 & 14,1 & 3,2 & $-24,6$ & 1,8 \\
\hline PL & 6,2 & 6,8 & 5,1 & 1,7 & 3,8 & 7,3 & 8,7 & 5,6 & $-1,0$ & 4,0 \\
\hline \multirow[t]{3}{*}{ RO } & 7,9 & 6,3 & 7,3 & $-7,1$ & $-1,3$ & 12,9 & 14,2 & 7,3 & $-12,9$ & $-1,0$ \\
\hline & \multicolumn{5}{|c|}{ Current Account Balance to GDP (\%) } & \multicolumn{5}{|c|}{ HICP* } \\
\hline & 2006 & 2007 & 2008 & 2009 & 2010 & 2006 & 2007 & 2008 & 2009 & 2010 \\
\hline BG & $-17,6$ & $-25,2$ & $-23,2$ & $-9,0$ & $-1,5$ & 7,4 & 7,6 & 12,0 & 2,5 & 3,0 \\
\hline $\mathrm{CZ}$ & $-2,1$ & $-2,6$ & $-0,8$ & $-1,2$ & $-2,3$ & 2,1 & 3,0 & 6,3 & 0,6 & 1,2 \\
\hline $\mathbf{E E}$ & $-15,7$ & $-17,2$ & $-8,8$ & 4,5 & 2,8 & 4,4 & 6,7 & 10,6 & 0,2 & 2,7 \\
\hline HU & $-7,7$ & $-7,0$ & $-6,9$ & $-0,4$ & 1,7 & 4,0 & 7,9 & 6,0 & 4,0 & 4,7 \\
\hline LV & $-22,5$ & $-22,3$ & $-13,1$ & 8,6 & 3,6 & 6,6 & 10,1 & 15,3 & 3,3 & $-1,2$ \\
\hline LT & $-10,4$ & $-15,1$ & $-13,1$ & 2,6 & 1,8 & 3,8 & 5,8 & 11,1 & 4,2 & 1,2 \\
\hline PL & $-3,0$ & $-5,1$ & $-4,8$ & $-2,2$ & $-3,1$ & 1,3 & 2,6 & 4,2 & 4,0 & 2,7 \\
\hline RO & $-10,6$ & $-13,6$ & $-11,4$ & $-4,2$ & $-4,2$ & 6,6 & 4,9 & 7,9 & 5,6 & 6,1 \\
\hline
\end{tabular}

Source: (European Commission, 2011)

The raise of the banking indebtedness level of households has an impact also on the efficiency of the monetary policy transmission mechanism. From this perspective, we can appreciate, synthetically, the fact that a high degree of the indebtedness level of households raises the sensibility of this sector to the modification of the key policy rate, while an excessive level of 
indebtedness limits the efficient transmission of the monetary policy decisions, because a very small part of the households fulfils the new terms laid down for the contracting of new loans in order to enhance the consumption volume.

The rapid growth of the households indebtedness, especially in foreign currency, and also the implied macroeconomic and financial vulnerabilities have determined certain reactions from the central banks and the supervisory authorities of the panel countries, materialised especially in the adoption of monetary policy, prudential, supervisory and especially administrative measures, in order to diminish the rapid growth of loans. According to the academic literature (Geršl and Seidler, 2011: 113) the number of adopted measures has been in close correlation with the growth rate of the banking loans and implicitly the growth rate of the households banking indebtedness level, as we can see from fig. no. 10. However, the efficiency of these measures has been limited if we take into account the fact that the full mobility of capitals is a reality in these countries. Furthermore, the high level of loans granted in foreign currencies has contributed to the exposure of banks to the currency risk. All these meant the diminishing of the vigilance of central banks and supervisory authorities toward the problem of loans denominated in foreign currencies. In the current context, the problems determined by the loans denominated in foreign currencies for the financial stability and the efficiency of the monetary policy have determined the authorities from the panel countries to adopt a series of new measures that are addressing this issue. For example: in Hungary, in August 2010, the Parliament adopted a regulation that has banned the granting of this type of loan, while in Poland there is an incentive to introduce a 50\% limit for the share of exposures open to FX risk in the entire bank's portfolio of retail credit exposures financing real estate, introducing the obligation for the bank to justify the adopted maximum level of loan-to-value ratio (LTV). At the same time, the major negative impact of the strong growth of the mortgage debts on financial stability implies that central banks and supervisor authorities must continuously track the evolutions of the real estate market and receive a more granular or differentiated analysis of household indebtedness in order to evaluate if the level of households indebtedness represents a risk for the financial system (BIS, 2009: 127). In most of the panel countries, the central banks are making analysis's based on the surveys and stress tests undertaken and inform the public through Financial Stability Reports regarding the risks that household's indebtedness represents.

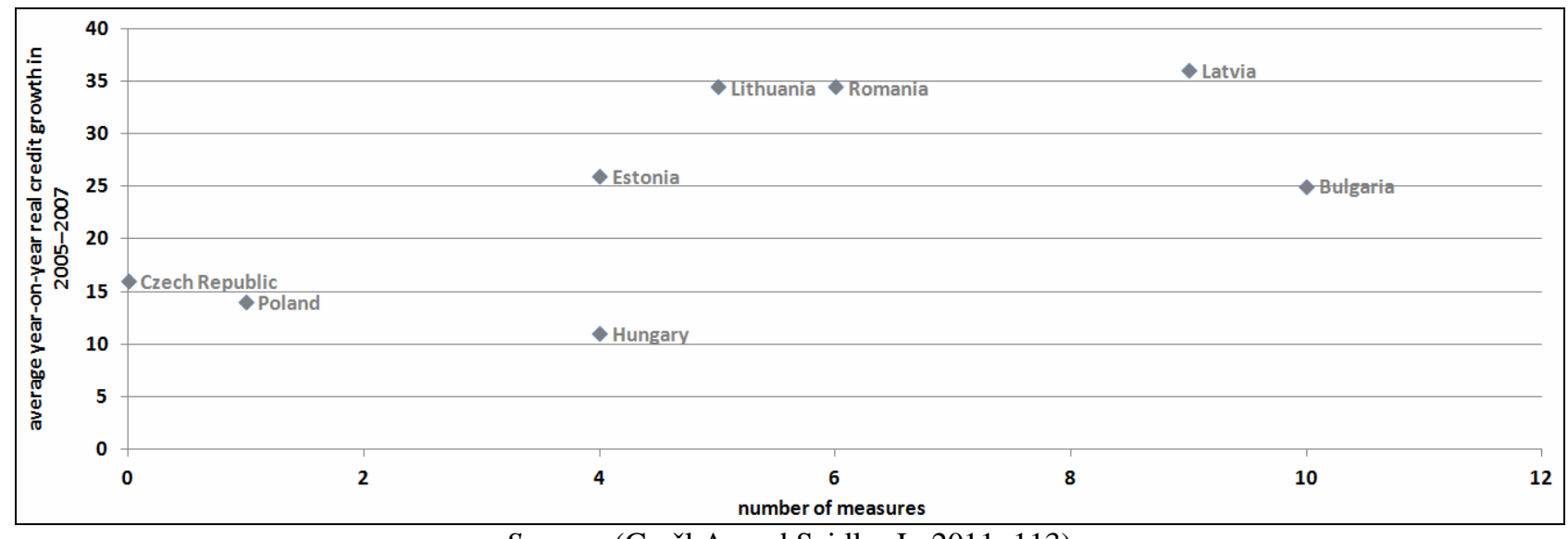

Source: (Geršl A. and Seidler J., 2011: 113)

Fig. no. 10 - The real growth rate of loans and the number of measures adopted by the central banks and the supervisory authorities in order to limit the over expansion of loans

According to an IMF (2006: 47) study, in order to avoid the accumulation of macroeconomic and financial vulnerabilities generated by the extremely rapid growth of the loans granted to households and implicitly the enhancement of the indebtedness level of this sector, the policymakers from the emerging countries should act simultaneously in four key fields, namely: 
prudent macroeconomic management in order to ensure the minimisation of the shocks related to interest rates and currency exchanges; the introduction of prudential norms in the case of households loans; the development of the juridical and regulatory framework and the amelioration of the information availability which will allow a better evaluation and diminishing of the systemic risks.

In the context of the global economic crisis which started in September 2008, in all the panel countries there has been registered a significant diminishing of the banking loans granted to the economy, including to the households sector. Such an evolution was the direct result of the significant contraction of the supply and the demand of credits. The reduction of the supply was determined by liquidity issues that existed on the international financial markets and which have affected the foreign banks that had subsidiaries opened in the analyzed countries and also by the increased risk aversion of the banks, which have raised their standards and terms in regard to credit operations. The diminishing of the demand for credits was determined especially by the increase of the credit costs, the depreciation of the national currencies from the analysed countries and the high volatility of the exchange rates and also because of the diminishing of the incomes, the rise of the unemployment and the uncertainties regarding the availabilities of jobs.

The pronounced reduction of the bank lending activity has had significant implications for the housing market, leading to a dramatic decrease in housing prices and implicitly the diminishing real estate collateral, which threatened the financial stability. For example in the case of the pane countries, the housing prices have dropped severally between September 2008 and the forth trimester of 2010, especially in Latvia with over 52\%, Lithuania and Estonia with 46\% (National Bank of Hungary, 2011: 29). Such a fluctuation of the prices had a negative influence also on the consumption through the direct wealth effects, but also through the restriction of the access to loans because of the diminishing in the collateral value.

As a result of the economic downturn, the diminishing of the available income, the raise in the unemployment rate, the depreciation of the national currencies and the drop of the assets value (especially of the real estate's value) the economic and financial situation of an important part of households has deteriorated, resulting in the contraction of the demand for goods and services and also of the supply, but also in a adjustment of the current account balance (see table no. 3). Moreover, a part of the households were unable to fulfil their debts towards banks, which has determined a drop in the quality of the bank's loans portfolio. The unavailability of statistical data in the case of the panel countries has prevented us from empirically underling the ratio of nonperforming loans in the case of the households sector. But, overall, the banking sector from the analysed countries has registered an increase in the ratio of non-performing loans (see table no. 4), especially in Latvia, Lithuania and Romania. In this context the banks being forced to create additional provisions which had an important impact on their profitability. Thus, the profitability indicators were substantially depreciated, especially in the Baltic States.

Table no. 4

Capital adequacy index and the indicators of banking sector soundness ${ }^{1}$

\begin{tabular}{|c|c|c|c|c|c|c|c|c|c|}
\hline \multirow[b]{3}{*}{ BG } & \multicolumn{3}{|c|}{$\begin{array}{c}\text { Bank non-performing loans to } \\
\text { total loans }\end{array}$} & \multicolumn{3}{|c|}{ ROA } & \multicolumn{3}{|c|}{ ROE } \\
\hline & 2008 & 2009 & 2010 & 2008 & 2009 & 2010 & 2008 & 2009 & 2010 \\
\hline & 2.5 & 6.4 & 11.9 & 2.1 & 1.1 & 0.9 & 23.1 & 10.2 & 7.9 \\
\hline $\mathbf{C Z}$ & 3.3 & 5.4 & 6.6 & 1.2 & 1.5 & 1.4 & 21.7 & 25.8 & 23.1 \\
\hline $\mathbf{E E}$ & 1.9 & 5.2 & 5.4 & 1.2 & -2.8 & 0.3 & 13.4 & -24.6 & 2.1 \\
\hline HU & 3.0 & 6.7 & 9.1 & 0.8 & 0.7 & 0.1 & 11.6 & 9.4 & 1.3 \\
\hline $\mathbf{L V}$ & 3.6 & 16.4 & 19.0 & 0.3 & -3.5 & -1.6 & 4.6 & -41.6 & -20.4 \\
\hline LT & 4.6 & 19.3 & 19.7 & 1.0 & -4.2 & -0.3 & 13.5 & -48.4 & -4.7 \\
\hline PL & 4.5 & 8.0 & 8.8 & 1.5 & 0.8 & 1.1 & 20.5 & 10.4 & 12.7 \\
\hline RO & 2.8 & 7.9 & 11.9 & 1.6 & 0.2 & -0.1 & 17.0 & 2.9 & -1.0 \\
\hline
\end{tabular}

${ }^{1}$ BG, EE,HU, LV, LT, PL, RO - December; CZ - September 


\section{Source: (IMF, 2011)}

The negative impact of the recent financial and economic crisis on the financial situation of households and on the quality of the bank's loans portfolio has determined, in most of the panel countries, a intensification of the debt restructuring process, which was trigger both by the request of the debtors and the own initiative of the banks. In addition, in some panel countries, the debt restructuring process was conducted also through the direct implication of governments. For example, in Hungary in November 2008, the commercial banks which were facing a increase of the credit risks linked to the portfolio of loans denominated in foreign currencies have signed a agreement with the Finance Ministry regarding the implementation of a debt restructuring program for the loans denominated in foreign currencies. Such a program offered mainly the possibility for borrowers to request an extension of the loan duration free of charge if there is a significant rise in their monthly repayments, or in the case of unemployed they were allowed to require a temporary easing of repayment obligations (Laeven and Laryea, 2009: 19).

The macroeconomic and financial imbalances recorded by the countries that in the years previous to the outbreak of the current global crisis have registered a rapid and unsustainable growth of the loans, as well as the extreme negative effects of the crisis on the banking sector, emphasizes the international financial system major gaps regarding the institutional and regulatory framework. In this context, the efforts in order to reform the financial system have been enhanced. From the regulatory point of view, the adoption of the Basel III accord by The Basel Committee on Banking Supervision has a major importance, which in terms of the banking lending activity makes reference to an important macro-prudential tool, namely "countercyclical capital buffer", meant to, especially, prevent excessive lending periods and banking systems crashes (Basel Committee on Banking Supervision, 2010). Regarding the institutional framework, for example, at the EU level, came into operation on 1 January 2011 the European System of Financial Supervision, which major objective is the macro-prudential supervision of the EU financial system.

In the current context, we can state that the central banks and the supervisory authorities are facing new challenges regarding the level of household indebtedness. From this perspective, a major challenge is related to the mortgage market, which unlike the consumer credit market does not have at this point a specific European regulation. Another challenge is represented by the high ratio of households banking debts denominated in foreign currencies. Regarding this aspect, it is necessary to strengthen the cooperation with the authorities from the home countries of the foreign banks which operate in the panel countries, but also the promotion of new actions in order to raise the level of financial education of households.

\section{Conclusion}

Our research underlines the fact that most of the new EU member countries from our panel have registered in the last years previous to the start of the global crisis in September 2008 a rapid expansion of the banking loans granted to households, as a result of the favourable international and national economic environment, the readjustment of the banks focus toward the retail segment and the raise of the competition on this segment. Such an evolution has lead, based on the data from our research, to the amplification of the households banking indebtedness and especially to a high growth rate of this indicator, which enhanced the sensitivity of the households to shocks from the variation of incomes, interest rate and the price of assets, especially of the real estate values.

As it results from our research, the rapid growth of the banking indebtedness of the private sector, and especially of the households, has lead to major macroeconomic and financial imbalances. Thus, as we have underlined, from a macroeconomic perspective, some of the panel countries have registered a raise of the inflation, an increase of the current account deficit and of the foreign debts. Meanwhile, from a financial perspective, the significant raise of the debt mortgages and especially of the ones with a variable interest rate and denominated in foreign currencies, has lead to a significant increase of the housing prices, the exposure of households to currency and 
interest rate risk, the enhancement of the bank's credit risk and the exposure of these institutions to the evolutions of the real estate market.

In most of the countries taken under study, the current global crisis has had very negative effects on the bank loans granted to households. Thus, as we have highlighted in our work, the reduction of the banking lending activity to households has led to a dramatic decrease in housing prices and implicitly the diminishing of the real estate collateral, which threatened the financial stability.

As a result of the economic downturn, the diminishing of the available income, the raise in the unemployment rate, the depreciation of the national currencies and the drop of the assets value (especially of the real estate's value) the economic and financial situation of an important part of households has deteriorated. Thus, a part of the households were unable to fulfil their debts towards banks, which has determined a drop in the quality of the bank's loans portfolio. Therefore, in our opinion, through its very serious effects the current crisis emphasizes the crucial importance for policy makers, both from macroeconomic and microeconomic level, to know and to understand the household responses in the face of macroeconomic shocks, reactions which depend on the size of income and the debt of this sector. Also, from our point of view, the assessment, understanding and rigorous monitoring of households' bank indebtedness structure (especially in terms of the currency, the purpose for which the bank loans were contracted, the maturity of bank loans) as well as the risks arising from the structure and the evolution of the liabilities and assets of this sector, provides significant information for central banks and supervisory authorities, which are necessary in order to be able to identify appropriate measures to limit or stimulate households' bank lending activity.

The vulnerabilities accumulated by some panel countries as a result of the rapid growth of the households banking indebtedness and which were aggravated in the context of the recent global crisis, but also the manifestation of new imbalances in the context of the economic downturn underline from our point of view the major importance that the insurance of a sustainable indebtedness level for household has for the economic and financial stability. Such a consideration is motivated by the fact that an unsustainable level of household's indebtedness generates a increase of the vulnerabilities of this sector in the face of macroeconomic shocks, with a significant negative impact on the demand and supply of goods and service, but also on the quality of the bank's loans portfolio this fact being sustained also by the findings of our research.

In our opinion, the extremely negative implications of the excessive household's indebtedness underline the necessity for the central banks and supervisory authorities to channel their efforts, in the post crisis period, to permanently track the financial situation of households and to identify new ways to enhance the level of financial education in this sector, in order to avoid future accumulation of imbalances and the manifestation of financial and economic crisis.

Although our research has certain limitations, arising from the fact that it is based only on aggregate data and aggregate indicators, our results are in line with the studies mentioned in the literature review that we have conducted, especially with the ones carried out by Hilbers et al (2005), Sirtaine et Skamnelos (2007), Cecchetti, Mohanty et Zampolli (2011) and Neagu and Margarit (2005).

Nevertheless, our research is one of the few ones which analyses the impact of the current financial and economic crisis on the indebtedness level of households in the case of the new EU members states, underling the major importance of ensuring a sustainable level of this indicator and thus becoming a good reference point for further researches. 


\section{References}

1. Backé P., Égert B., and Walko Z., 2007. Credit Growth in Central and Eastern Europe Revisited. Focus on European Economic Integration Q2, OeNB.

2. Basel Committee on Banking Supervision, 2010. Consultative Document- Countercyclical capital buffer proposal, July.

3. BIS, 2009. Household debt: implications for monetary policy and financial stability, Papers No. 46.

4. Büyükkarabacak B., Valev N. T., 2010. The role of household and business credit in banking crises. Journal of Banking \& Finance, Volume 34, Issue 6, pp. 1247-1256.

5. Cecchetti S.G., Mohanty M. S., Zampolli F., 2011. The real effects of debt. BIS Working Papers, No. 352.

6. Debelle G., 2004. Household debt and the macroeconomy. BIS Quarterly Review, March.

7. ECB, 2010. Banking structures, September.

8. ECB, 2009. Housing finance in the euro area, Occasional Paper series No. 101.

9. ECB, 2008. Banking structures, October.

10. European Commission, 2011. European Economic Forecast. Spring. European Economy No. 1.

11. ECRI, 2010. Consumer Credit in Europe (1995-2009). Statistical Package, Brussels.

12. Eurostat, 2009. Statistics in focus, No. 32.

13. Geršl A., Seidler J., 2011. Excessive credit growth as an indicator of financial (in)stability and its use in macroprudential policy, in Financial Stability Report 2010/2011. Czech National Bank.

14. Hilbers P., Otker-Robe I., Pazarbasioglu C., Johnsen, G., 2005. Assessing and Managing Rapid Credit Growth and the Role of Supervisory and Prudential Policies, IMF Working Paper WP/05/151.

15. IMF, 2011. Global Financial Stability Report. April.

16. IMF, 2006. Household Credit Growth in Emerging Market Countries, Chapter II in Global Financial Stability Report. September.

17. Karen D., and Kohn D.L., 2007. The Rise in U.S. Household indebtedness: Causes and Consequences, Finance and Economics Discussion Series 2007-37, Washington: Board of Governors of the Federal Reserve System.

18. Laeven L., and Laryea Th., 2009. Principles of Household Debt Restructuring. IMF Staff Position Note, June.

19. National Bank of Hungary, 2011. Report on Financial Stability, April.

20. National Bank of Hungary, 2009. Report on Financial Stability, April.

21. Neagu F., Mărgărit A., 2005. Risks for the Romanian financial stability arising from the households sector, Occasional Papers no. 14.

22. Sirtaine S., and Skamnelos I., 2007. Credit growth in emerging Europe: a cause for stability concerns? Policy Research Working Paper Series 4281. The World Bank.

23. AMECO, http://ec.europa.eu/economy_finance/ameco/

24. Eurostat, http://epp.eurostat.ec.europa.eu/portal/page/portal/eurostat/home/ 